Ткачов Валерій Анатолійович аспірант кафедри менеджменту і логістики Одеської національної академії харчових технологій, вул. Канатна, 112, м. Одеса, 65039, тел.: (048) 712-41-14, e-mail: tkachevvaleriy@gmail.com, https//orcid.org/0000-0003-6587-6827

\title{
ПРОБЛЕМИ ФОРМУВАННЯ СТРУКТУРИ ЛОГІСТИЧНИХ ВИТРАТ ПІДПРИСМСТВ РІЧКОВОГО ТРАНСПОРТУ УКРАЇНИ
}

Анотація. У статті досліджено структуру та стан річкового транспорту України, технічний стан об'єктів, які безпосередньо здійснюють транспортування вантажів, та об'єктів, які забезпечують роботу річкового транспорту. Здійснено аналіз кваліфікації видів транспорту України, досліджено динаміку обсягів перевезень вантажів різними видами транспорту за останні роки. Перевезення вантажів річками, виступає одним із найдавніших видів транспортування. Враховуючи, що сутністю діяльності річкового транспорту виступають послуги 3 переміщення вантажів, проведено моніторинг сектору вантажних перевезень внутрішніми водними шляхами, згідно КВЕД-2010: 50.40. Досліджено склад витрат річкового транспортування вантажів та структуру операційних витрат типового каботажного транспортування. Визначено види зборів, які законодавчо затверджені в Україні при проходженні суден по фарватеру рік, каналів, шлюзів, інших гідротехнічних споруд, які суттєво впливають на конкурентоспроможність галузі в цілому. Проаналізовано структуру логістичних витрат підприємств річкової галузі в каботажному та міжнародному плаванні. Проведено огляд досліджень науковців, щодо логістичних витрат різних функціональних областей логістики. Визначено, що логістичні витрати підприємств транспортної галузі мають різну структуру i залежать від виду транспорту: автомобільного, залізничного, трубопровідного, річкового, морського, авіаційного, інших видів. Означено проблеми законодавчого рівня 3 формування оптимальних структур логістичних витрат річкового транспорту. Розглянуто проблемні моменти функціонування річкової галузі: не урегульованість питання забезпечення лоцманських проводок суден на ріках, відсутність державної компенсації акцизу на дизельне пальне для внутрішнього судноплавства. Означено конфліктність інтересів бізнесу, щодо ряду положень Закону «Про внутрішній водний транспорт». Досліджено природні можливості розвитку річкового транспорту в Україні: наявність внутрішніх водних шляхів міжнародного значення та річкових 
портів міжнародного значення.

Ключові слова: річковий транспорт, судна, підприємства річкового транспорту, порти, причали, ремонтно-експлуатаційні бази, збори, логістичні витрати.

Tkachov Valeriy Anatoliyovych Graduate student of the Department of Management and Logistics of the Odessa National Academy of Food Technologies, Kanatna St., 112, Odessa, 65039, tel.: (048) 712-41-14, e-mail: tkachevvaleriy@gmail.com, https // orcid.org / 0000-0003-6587-6827

\section{PROBLEMS OF FORMATION OF THE STRUCTURE OF LOGISTICS COSTS OF ENTERPRISES OF RIVER TRANSPORT OF UKRAINE}

Abstract. The article examines the structure and condition of river transport in Ukraine, the technical condition of facilities that directly transport goods, and facilities that ensure the operation of river transport. The analysis of qualification of types of transport of Ukraine is carried out, dynamics of volumes of transportations of freights by different types of transport for the last years is investigated. Transportation of goods by rivers is one of the oldest types of transportation. Taking into account that the essence of river transport activity is cargo movement services, the inland waterway freight sector was monitored, according to NACE-2010: 50.40. The composition of the costs of river transportation of goods and the structure of operating costs of typical cabotage transportation are studied. The types of fees that are legally approved in Ukraine for the passage of vessels on the fairway of rivers, canals, locks, and other hydraulic structures, which significantly affect the competitiveness of the industry as a whole. The structure of logistics costs of river industry enterprises in cabotage and international navigation is analyzed. A review of research by scientists on the logistics costs of various functional areas of logistics. It is determined that the logistics costs of transport enterprises have a different structure and depend on the type of transport: road, rail, pipeline, river, sea, aviation and other types. The problems of the legislative level on the formation of optimal structures of logistics costs of river transport are identified. The problematic moments of the river industry functioning are considered: the unresolved issue of providing pilotage of vessels on rivers, the lack of state compensation for excise duty on diesel fuel for inland navigation. Conflict of interests of business concerning a number of provisions of the Law "About internal water transport" is defined. The natural possibilities of river transport development in Ukraine have been studied: the presence of inland waterways of international importance and river ports of international importance. 
Keywords: river transport, vessels, river transport enterprises, ports, berths, repair and maintenance bases, fees, logistics costs.

Постановка проблеми. Перевезення вантажів річками, виступає одним із найдавніший видів транспортування. Річкові та караванні перевезення започатковані людиною на зорі людської діяльності як для господарчих потреб, так і в процесі обміну товарами. Однак річкові перевезення, у порівнянні із караванними, мали ряд переваг: більша швидкість, більша вантажопідйомність, більша схоронність товару, при відносно малих транспортних витратах. До негативних ознак можна віднести (для північних річок) - відсутність цілорічної навігації, у зв'язку із замерзанням річок i, безумовно, відсутність річок на певних територіях. 3 плином часу, караванні перевезення, скоротилися в рази, що пов'язано із розвитком інших технічних видів транспорту, а річкові перевезення продовжують відігравати стратегічну роль в транспортному комплексі ряду країн.

Аналіз останніх публікацій по проблемі. Широка сфера логістизації процесів в галузях національної економіки, спричинила багатогранні наукові дослідження феномену логістики, логістичних витрат та знайшли своє відображення у працях вітчизняних науковців Є. Крикавського, Є. Новопісної, М. Окландера, М. Рета, І. Савенка, І. Седікової, О. Сумця. Питаннями розвитку логістики займались й зарубіжні науковці такі дослідники як А. Гаджинський, Л. Миротін, Д. Уотерс, Д. Бауерсокс, Д. Ламберт та інші.

Мета статті $\epsilon$ визначення проблем формування логістичних витрат для підприємств річкового транспорту, їх узагальнення, дослідження шляхів підвищення конкурентоспроможності галузі

Виклад основного матеріалу. До логістичних витрат в транспортній галузі відносять витрати, пов'язані з переміщенням та одночасним зберіганням товарноматеріальних цінностей, від первинного джерела їх започаткування до кінцевого споживача у вигляді сировини, напівфабрикатів та готової продукції. Логістичні витрати мають певну специфіку в різних функціональних областях логістики: постачання, виробництво, дистрибуція, зберігання, транспортування.

Є. Крикавський розкриває термін «логістичні витрати» через наступне визначення - «це сума витрат на управління та реалізацію логістичних процесів в окремих межах переміщення матеріальних потоків» [1].

Є. Новопісна у своєму дослідженні «Управління проєктами та розвиток виробництва» акцентує увагу на задачах, притаманних логістичним витратам які «... супроводжують рух матеріального потоку, формуються паралельно з ним, та виконують головну задачу логістичної системи: доставку товару в потрібне місце, в потрібній кількості, за певний термін і при заданому рівні витрат» [2]. 
М. Окландер характеризуючи логістичні витрати, вважає, що це «...витрати, які пов’язані з рухом і зберіганням товарно-матеріальних цінностей, починаючи від вибору постачальника i закінчуючи доставкою готової продукції та обслуговуванням споживача» [3].

М. Рета в роботі [4] надає поняттю логістичні витрати більш широкого значення, а саме: «це грошове вираження сукупності витрачених матеріальних, трудових, фінансових, інформаційних ресурсів та операцій 3 переміщення матеріальних потоків у межах логістичної системи» [4].

I. Савенко дає наступне визначення дефініції «частина загальних витрат, понесених підприємством при логістичному забезпеченні створення цінностей у вигляді готової продукції чи послуги, i які покупець згоден i в змозі компенсувати через купівлю, вважаючи дану цінність для себе важливою» [5].

О. Сумець в дослідженні [6] визначає, що це «витрати на виконання в логістичній системі усіх логістичних активностей, що пов'язані безпосередньо 3 логістичними потоками в межах визначеного простору і часу» [6]. Науковець справедливо зауважує, що основна проблема, яка виникає під час виділення логістичних витрат, полягає в тому, що нормативні документи відповідних державних органів і служб щодо бухгалтерського обліку витрат не містять методик ідентифікації витрат, пов'язаних із логістичними процесами.

I. Седікова та Д. Седіков визначають, що «логістичні витрати являють собою витрати трудових, матеріальних, фінансових та інформаційних ресурсів, зумовлені виконанням підприємствами своїх функцій з виконання замовлень споживачів» [15]. Незважаючи на достатньо широкі дослідження, питанню логістики та логістичних витрат на річковому транспорті приділено мало уваги. Враховуючи важливість розвитку річкової галузі та суперечливі підходи законодавців та бізнесу до законодавчої бази функціонування галузі дану тематику слід розширювати.

Транспортна галузь є провідною в українській економіці, яка створює $13 \%$ ВВП країни, складає 35 \% від загальної вартості виробничого потенціалу, забезпечує робочими місцями 5 \% працездатного населення [6]. До структури єдиної транспортної системи України входять: транспорт загального користування, шляхи сполучення загального користування, трубопровідний транспорт, промисловий залізничний транспорт, відомчий транспорт [8]. Метою єдиної транспортної системи $є$ забезпечення суспільного виробництва i національної безпеки транспортними послугами (складування та технологічна підготовка вантажів до транспортування), забезпечення зовнішньоекономічної діяльності.

Згідно загального Класифікатора «Галузі народного господарства України» до сфери матеріального виробництва відносять галузі, які створюють матеріальні 
блага у формі продукції, енергії, переміщення вантажів. Таким чином до сфери матеріального виробництва відноситься транспорт. Класифікація видів транспорту України наведено на рис. 1.

Об'єктом даного дослідження $є$ механізми формування структури логістичних витрат підприємств внутрішнього водного транспорту. Останнім часом в Україні та інших країнах світу річкові перевезення перебувають у кризовому стані.

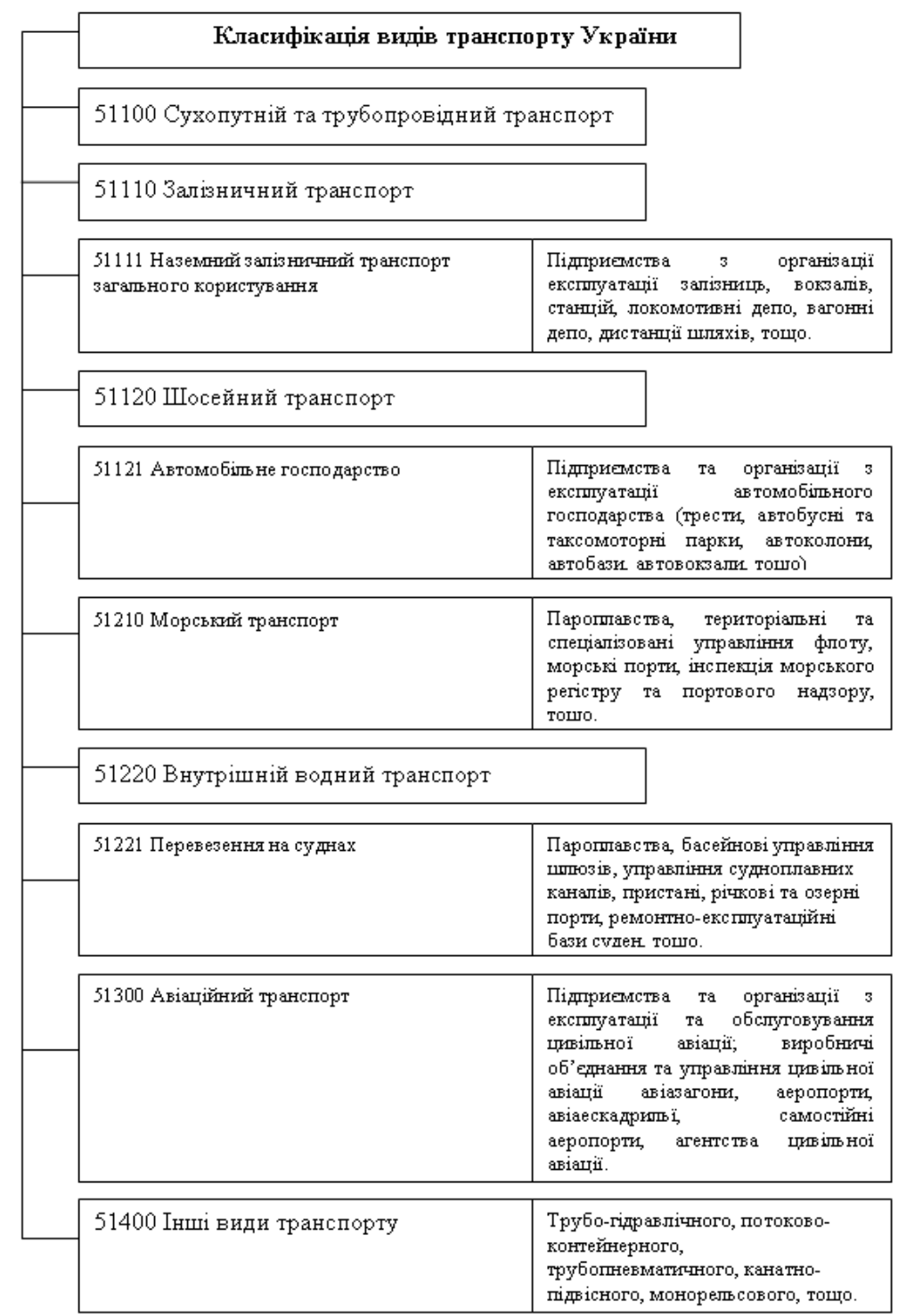

\section{Рис. 1. Класифікація видів транспорту України}

Джерело: побудовано автором на основі [9]

Уповільнення економічного розвитку призвело до зменшення внутрішніх транспортних водних шляхів, що завдало шкоди флоту Європейського Союзу. Завдяки своїм перевагам (найдешевшим після трубопровідного) на внутрішній водний транспорт припадає приблизно 65 \% світового вантажообігу. Будівельні матеріали, вугілля, руду та зерно, які не потребують особливої швидкості, транспортуються внутрішніми водними шляхами. Загальна довжина шосейних 
доріг в Україні становить 169491 км, залізниць - 22473 км [10].

Таблиия 1

Сектор вантажних перевезень ВВШ в класифікаторах КВЕД-2010: 50.40. Вантажний річковий транспорт

\begin{tabular}{|c|c|c|}
\hline $\begin{array}{l}\text { Бізнес- } \\
\text { процес }\end{array}$ & Код СКП & Послуга, що стосується процесу \\
\hline \multirow{7}{*}{$\begin{array}{l}\text { Вантажні } \\
\text { перевезення } \\
\text { внутрішніми } \\
\text { водними } \\
\text { шляхами }\end{array}$} & $\begin{array}{l}50.40 .11- \\
14 \\
50.40 .19\end{array}$ & $\begin{array}{l}\text { Послуги річкового транспорту з перевезення заморожених } \\
\text { чи охолоджених продуктів суднами-рефрижераторами, } \\
\text { танкерами сирої нафти, танкерами інших безтарних рідин і } \\
\text { газів, суднами-контейнеровозами змішаних вантажів, інші }\end{array}$ \\
\hline & 50.40 .21 & $\begin{array}{l}\text { Послуги з надання в оренду вантажного річкового } \\
\text { транспорту з екіпажем }\end{array}$ \\
\hline & 50.40 .22 & Послуги з буксирування та штовхання річкою \\
\hline & 52.22 .11 & $\begin{array}{l}\text { Послуги } 3 \text { експлуатації морських портів та водних шляхів } \\
\text { (крім послуг } 3 \text { оброблення вантажів ) }\end{array}$ \\
\hline & 52.22 .12 & $\begin{array}{l}\text { Послуги з експлуатації річкових портів та водних шляхів } \\
\text { (крім послуг з оброблення вантажів) }\end{array}$ \\
\hline & 52.22 .13 & $\begin{array}{l}\text { Послуги з лоцманського проведення та швартування } \\
\text { морських транспортних засобів }\end{array}$ \\
\hline & 52.22 .14 & $\begin{array}{l}\text { Послуги з лоцманського проведення та швартування } \\
\text { Річкових транспортних засобів }\end{array}$ \\
\hline
\end{tabular}

Джерело: складено автором за даними [11]

Довжина річкових судноплавних шляхів 3 початку 90-х років скоротилася до 1672 км ( $\downarrow 2241$ км). У 1991 р. обсяг вантажоперевезень становив 65 млн. т/рік, у 2010 році - 7 млн. т, у 2016 - 6 млн. т/рік. Обсяги перевезень за 2014-2018 роки наведено на рис. 2.

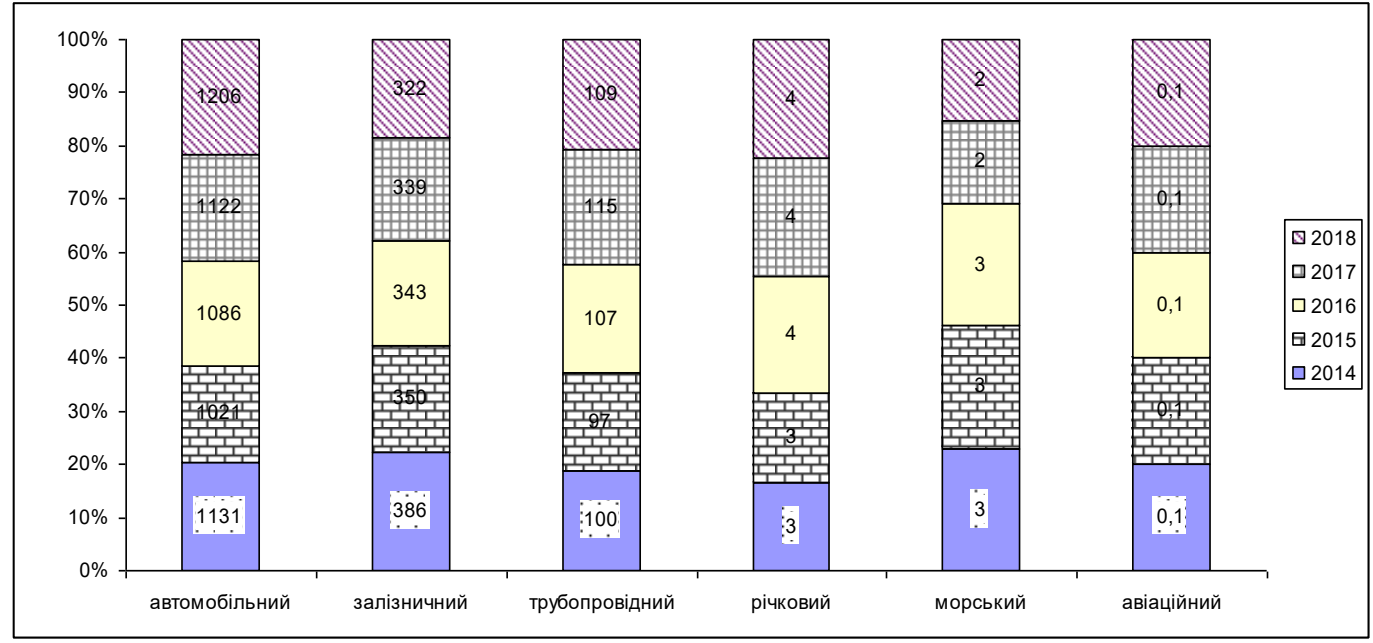

Puc. 2. Динаміка обсягів перевезень вантажів за видами транспорту, (млн. т). Джерело: розраховано автором за [10] 
За 2016-2019 роки спостерігалось відновлення річкових перевезень: вантажоперевезення по Дніпру $\uparrow$ на 83 \% та склали 11,79 млн. т. Обсяги перевезення внутрішніми водними шляхами в Україні складає менше 1 \% від сумарних транспортних перевезень що у порівнянні 3 європейськими $\epsilon$ невисокими показниками. Так, наприклад, в Нідерландах частка перевезень в загальній сумі перевезень складає $30 \%$, в Румунії - $21 \%$, Німеччині - $13 \%$, в Угорщині - 4 \%, середній показник по країнах $С \mathrm{C}-6,5 \%$. Щодо низьких витрат: європейський річковий транспорт у 1,5 рази менше споживає енергії ніж залізничний та у 3,5 рази менше ніж автомобільний [7]. Структура річкового транспорту України наведено на рис. 3.

\begin{tabular}{|c|c|}
\hline \multicolumn{2}{|c|}{ Структура річкового транспорту України } \\
\hline$\downarrow$ & $\downarrow$ \\
\hline $\begin{array}{c}\text { О6'єкти галузі, які } \\
\text { безпосередньо здійснюють } \\
\text { транспортування }\end{array}$ & $\begin{array}{l}\text { O6'єкти галузі, які забезпечують } \\
\text { роботу річкового транспорту }\end{array}$ \\
\hline$\downarrow$ & $\downarrow$ \\
\hline $\begin{array}{l}\text { 1. Підприємства річкового } \\
\text { транспорту, що здійснюють } \\
\text { перевезення пасажирів i } \\
\text { вантажів, багажу, пошти. } \\
\text { 2. Порти і пристані. } \\
\text { 3. Судна. }\end{array}$ & 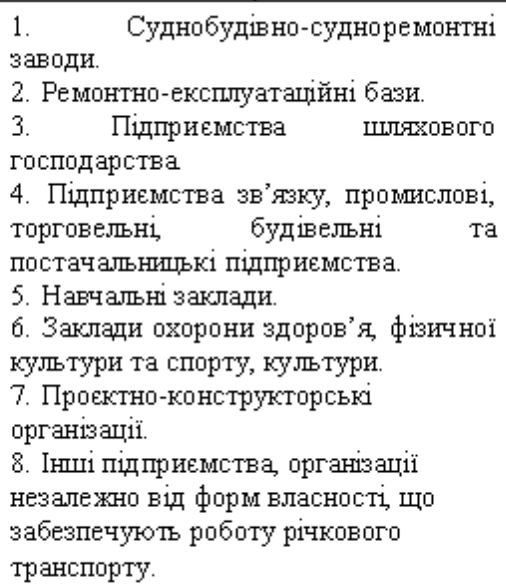 \\
\hline
\end{tabular}

\section{Puс. 3. Структура річкового транспорту України}

Джерело: побудовано автором за даними [8]

Для аналізу діяльності річкового транспорту важливим є характеристика та групування засобів транспортування, у нашому дослідженні судна, які експлуатуються на річках. Розподіл суден з метою справляння портових зборів, здійснюється за шістьма групами (А, Б, В, Г, Д, Е).

До групи А віднесено вантажні судна, які здійснюють вантажні операції та плавучі споруди. Групу Б складають пасажирські судна (швидкісні, на підводних крилах, пороми), які виконують вантажопасажирські функції. Групу В складають ліхтери, буксири (штовхачі), баржі (самохідні, несамохідні), річкові самохідні судна («ріка-море»), які виконують подальше перевантаження вантажів на морські судна і навпаки. Групу Г складають несамохідні судна (крім барж). До групи Д віднесено судна, які заходять вимушено на карантинні обмеження або 
прямують на ремонт на судноремонтні підприємства України. До останньої групи Е віднесено інші судна (судноремонтного заводу, аварійно-рятувальні, підводнотехнічні, госпітальні, гідрографічні, портового флоту, спортивні, приватні яхти, парусні, риболовні) [12]. Транспортування виступає однією із важливих функціональних областей логістики. Виходячи із цього, всі витрати, щодо здійснення перевезень вантажів відносяться до логістичних. Узагальнені статті логістичних витрат наведено в таблиці 2.

Табличя 2

\section{Склад логістичних витрат річкового транспортування вантажів}

\begin{tabular}{|l|l|}
\hline $\begin{array}{l}\text { Функціональна } \\
\text { область }\end{array}$ & Склад логістичних витрат \\
\hline Транспортування & $\begin{array}{l}\text { Витрати, пов’язані 3 підготовкою продукції до відвантаження } \\
\text { (перевірка кількості, якості, маркування, упакування). }\end{array}$ \\
\cline { 2 - 3 } & Витрати на вантажно-розвантажувальні роботи. \\
\cline { 2 - 3 } & Операційні витрати перевезення вантажів судном. \\
\cline { 2 - 3 } & Витрати на зберігання продукції в пунктах перевантаження. \\
\cline { 2 - 3 } & $\begin{array}{l}\text { Витрати на технічне обслуговування та поточний ремонт } \\
\text { рухомого транспортного складу. }\end{array}$ \\
\cline { 2 - 3 } & Витрати на утримання виробничо-технічної бази річкової галузі. \\
\cline { 2 - 3 } & Витрати на утримання гідротехнічних споруд на річках. \\
\cline { 2 - 2 } & Витрати на днопоглиблювальні роботи. \\
\hline
\end{tabular}

Джерело: складено автором за даними [13]

В таблиці 2 інтегрованою статтею логістичних витрат виступає стаття «Операційні витрати перевезення вантажів судном». Дана стаття кардинально відрізняється сутністю від подібних в інших видів транспорту. У зв'язку з цим виникла потреба надати пояснення складових цієї статті (див. рис. 4).

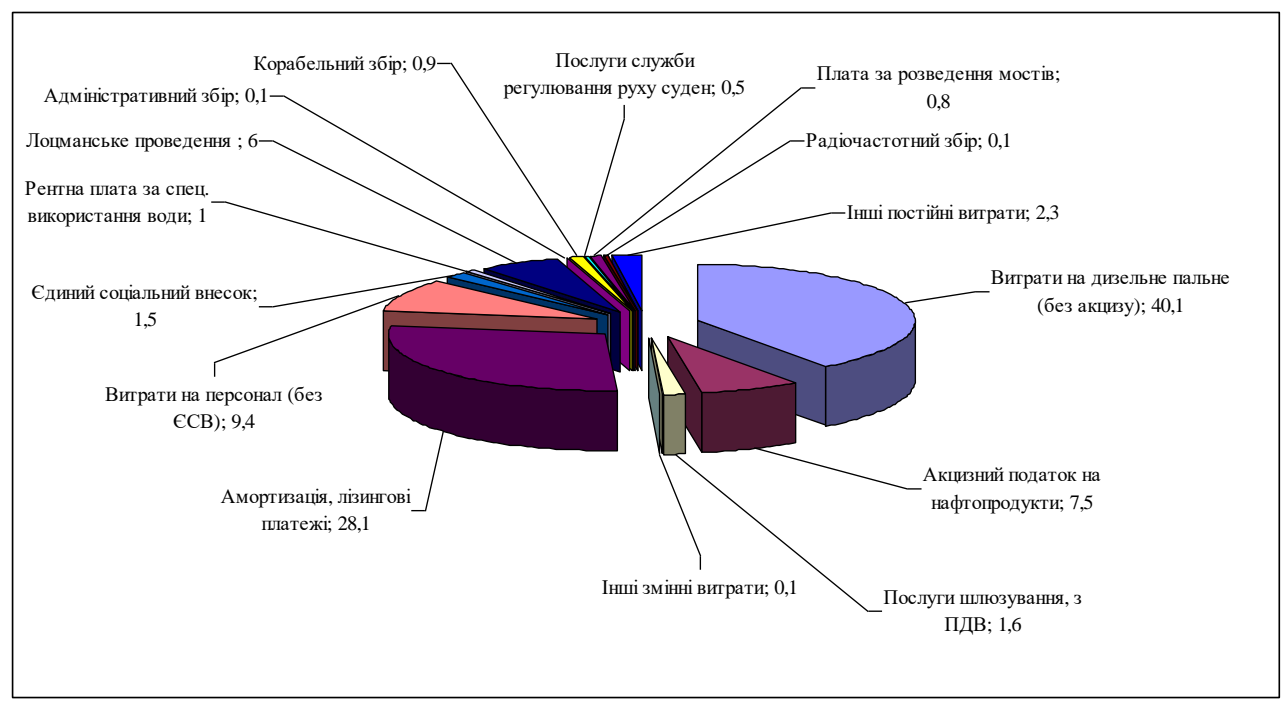

Pис. 4. Структура операційних витрат типового каботажного перевезення під украӥнським прапором

Джерело: складено автором за даними [14] 
На прикладі маршруту Миколаїв-Кременчук-Миколаїв - 1160 км. Тоннаж 4000 т, використання вантажоємності - 75 \%. Найбільшими статтями операційних витрат для типового каботажного перевезення по Дніпру є витрати на дизельне пальне (40-50 \%), амортизація та лізингові платежі (30 \%), витрати на персонал (11 \%) та акцизний податок на нафтопродукти (7-10 \%) Лоцманське проведення річковими лоцманами становить близько $6 \%$ та варіюється в широких межах в залежності від геометрії судна. В табл. 3 наведені розміри плати за проходження суден шлюзами Дніпровського каскаду.

Табличяя 3

\section{Розміри плати за проходження суден шлюзами Дніпровського каскаду (гривень за одне судно)}

\begin{tabular}{|c|c|c|c|c|c|c|c|}
\hline \multirow[t]{3}{*}{ Назва шлюзу } & \multirow{3}{*}{$\begin{array}{l}\text { Річковий } \\
\text { кілометр }\end{array}$} & \multirow{2}{*}{\multicolumn{2}{|c|}{$\begin{array}{l}\text { Габарити камери, } \\
\text { м }\end{array}$}} & \multicolumn{4}{|c|}{ Розміри плати } \\
\hline & & & & \multicolumn{4}{|c|}{ модуль судна, м³ } \\
\hline & & довжина & ширина & $\begin{array}{l}\text { до } \\
2000\end{array}$ & $\begin{array}{l}2001- \\
4000\end{array}$ & $\begin{array}{l}4001- \\
10000\end{array}$ & $\begin{array}{l}\text { понад } \\
10000\end{array}$ \\
\hline \multicolumn{8}{|c|}{ 1. Для суден у закордонному плаванні } \\
\hline Київський & 689 & 149 & 18 & 806 & 1241 & 1614 & 1981 \\
\hline Канівський & 727 & 290 & 18 & 806 & 1241 & 1614 & 1981 \\
\hline Кременчуцький & 555 & 270 & 18 & 806 & 1241 & 1614 & 1981 \\
\hline Середньодніпровський & 433 & 270 & 18 & 806 & 1241 & 1614 & 1981 \\
\hline Запорізький & 302 & 290 & 28 & 3344 & 4958 & 6569 & 8184 \\
\hline Каховський & 91 & 260 & 18 & 2169 & 3223 & 4337 & 5457 \\
\hline \multicolumn{8}{|c|}{ 2. Для суден у каботажному плаванні } \\
\hline Київський & 689 & 149 & 18 & 251 & 372 & 497 & 557 \\
\hline Канівський & 727 & 290 & 18 & 251 & 372 & 497 & 557 \\
\hline Кременчуцький & 555 & 270 & 18 & 251 & 372 & 497 & 557 \\
\hline Середньодніпровський & 433 & 270 & 18 & 251 & 372 & 497 & 557 \\
\hline Запорізький & 302 & 290 & 28 & 618 & 991 & 1241 & 1614 \\
\hline Каховський & 91 & 260 & 18 & 497 & 618 & 869 & 1112 \\
\hline
\end{tabular}

Примітка. Розміри плати не включають податок на додану вартість.

Джерело: побудовано автором на основі [13]

3 кінця 2015 року лоцманське проведення всіх суден, незалежно від прапора i форм власності судна, на річкових внутрішніх водних шляхах України здійснюється державними річковими лоцманами ДП «Дельта-Лоцман». Вартість лоцманського проведення по Дніпру показано в таблиці 4. 
Вартість лоцманського проведення по Дніпру

\begin{tabular}{|l|c|c|}
\hline \multirow{2}{*}{ Відрізок шляху } & \multicolumn{2}{|c|}{ Вартість лоцманського проведення, \$ США } \\
\cline { 2 - 3 } & закордонне плавання & каботажне плавання \\
\hline 1. Чорноморськ - Херсон & 240 & 687 \\
\hline $\begin{array}{l}\text { 2. Чорноморськ - Нова } \\
\text { Каховка }\end{array}$ & 963 & 336 \\
\hline 3. Чорноморськ - Запоріжжя & 1911 & 668 \\
\hline 4. Чорноморськ - Дніпро & 2285 & 799 \\
\hline 5. Чорноморськ - Кременчук & 2932 & 1025 \\
\hline 6. Чорноморськ - Київ & 4324 & 1511 \\
\hline
\end{tabular}

Джерело: розроблено автором за даними [14]

Згідно інформації Білоруського водного агентства триває лібералізації ринку річкових перевезень згідно із якими користування шлюзів в Білорусі безкоштовні, а внутрішні водні шляхи утримує держава. До проблемних моментів функціонування річкової галузі слід віднести:

До проблемних моментів функціонування річкової галузі слід віднести:

- загальнодержавне питання неконтрольованого скидання води ГЕС, що змінює глибини водних шляхів;

- у період 1990-2021 рр., загальна протяжність судноплавних шляхів скоротилася 35 тис. км до 2 тис. км.;

- коефіцієнт зносу основних фондів внутрішніх водних шляхів 0,75 , що $\epsilon$ високим для гідротехнічних та інших споруд річкового господарства. Кошти на капітальний ремонт шлюзів, які держава почала виділяти з 2017 року, освоюють не повною мірою. Наприклад, у 2019 році робіт було виконано лише на 22, 7 млн. iз 124,3 млн. грн. 81,7 \% не було виконано.

- дефіцит каботажного флоту та його високий середній вік - понад 30 років. Більш новий за віком (до 10 років) має на своєму балансі та експлуатується флот TOB CП «Нібулон» 75 одиниць: буксири проєкту POSS та несамохідні баржі NBL дедвейт - 4143 м, зерновий 140 метровий перевантажувач зерна NIBULON MAX класу «річка-море».

- не урегульованість питання забезпечення лоцманських проводок суден на piках. Лоцманський збір може складати до 20 тис. дол. за рейс, або до 7 дол. 3 тони для судна вантажоємністю до 3 тис. тон. Відповідальність лоцмана за коректність рекомендації не визначена.

- відсутність державної компенсації акцизу на дизельне пальне для внутрішнього судноплавства, який в загальній структурі операційних витрат складає $8 \%$; 
- згідно Закону «Про внутрішній водний транспорт», іноземні судна отримують конкурентні переваги шляхом несплати основних податків та зборів в Україні (акциз, ПДВ на пальне для суден, єдиний соціальний внесок), шляхом звільнення їх від сплати канального збору, що складає 50 \% від усіх портових зборів, при цьому іноземці користуватимуться всіма державними об'єктами інфраструктури річок безоплатно.

Незважаючи на означені проблеми, слід зазначити, що річковий транспорт має низку переваг перед автомобільним та залізничним, що створює передумови зміни логістичних маршрутів на користь перевезень внутрішнім водним транспортом:

1. У вантажопідйомності: при середній вантажопідйомності несамохідної баржі в 4000 т тонн вантажу, дві баржі та буксир замінять 200 автопотягів чи 130 залізничних вагони та два локомотиви.

2. Змінивши сухопутні логістичні маршрути на річку економія на ремонті автомобільних доріг протягом 4 років складе суму до 1 млрд. грн.

3. Екологічність: річковий транспорт $є$ найбільш екологічним, що дає йому переваги в конкурентній боротьбі з автомобільним та залізничним. Переміщення логістичних маршрутів на річку суттєво зменшить кількість шкідливих викидів вдовж автомобільних та залізничних магістралей в країні.

4. Природні можливості розвитку річкового транспорту в Україні: У «Блакитній книзі» СЕК ООН (1998р.) зазначено, що «довжина українських внутрішніх водних шляхів категорії «Е» міжнародного значення становить 1179 км, або 5 \% від загальної довжини європейських рік».

В Україні найдовші шляхи класу V (Дніпро від гирла до Києва). До інших класів шляхів категорії «Е» тут належать ділянка Дніпра вище Києва, p. Прип’ять, гирлова ділянка р. Південний Буг, р. Дунай (в тому числі українська ділянка основного русла Дунаю, що належить до найвищого VII класу). До портів міжнародного значення відносяться чотири українські порти на Дунаї - Рені, Ізмаїл, Кілія, Усть-Дунайськ та десять українських портів Дніпровського басейну та Білгород-Дністровський як гирловий порт Дністер. Означені можливості можуть забезпечити до 60 млн. тонн пропускної здатності на річках України.

Висновки. Провівши багатогранне дослідження функціонування річкового транспорту в Україні слід констатувати, що даний вид транспорту в нагальний час знаходиться в кризовому стані (інфраструктура, шлюзове господарство, заілювання фарватеру рік, застарілість та відсутність плавзасобів).

Однак по відношенню до інших видів транспорту, він має потенційні можливості розвитку за рахунок природних умов (річкового потенціалу), технікоекономічних переваг (низьких експлуатаційних витрат, надійності та екологічності). Не визначеними $є$ законодавча база i не повне співпадіння 
поглядів законодавців та бізнесу, щодо ряду положень Закону «Про внутрішній водний транспорт» в рамках організації каботажного та міжнародного плавання суден під іноземними прапорами на внутрішніх водних шляхах України. Розгляд означених проблемних моментів планується автором в подальших дослідженнях.

\section{תimepamypa:}

1. Крикавський Є. В. Навчально-методичний посібник. Львів: Видавництво Львівської політехніки. 2014. $196 \mathrm{c}$.

2. Новопісна Є. В. Фактори формування логістичних витрат підприємства. Управління проєктами та розвиток виробництва: Зб. наук. пр. Луганськ: вид-во СНУ ім. В. Даля. 2009. № 4 (32). C. $123-129$.

3. Окландер М. А. Логістика: Підручник. К.: Центр учбової літератури. 2008. 346 с.

4. Рета М. В. Логістичні витрати: визначення, класифікація та облік. Бізнесінформ. 2012. № 8. C. $155-158$.

5. Савенко I. І., Седіков Д. В. Логістичний менеджмент, як інструмент оптимізації логістичних витрат. Економіка харчової промисловості. Одеса. 2020. Вип. 3 Т. 12. С. 42- 50.

6. Сумец О. М. Логістичні витрати підприємств олійно-жирової галузі: формування та оцінювання: монографія. Харків : Вид-во НУА. 2017. 243 с.

7. Легенький Г. Проблеми розвитку транзитних перевезень та шляхи їх вирішення. Економіка України. 2019. №7. С. 8

8. Закон України «Про транспорт» № 232/94-BP від 10.11.1994. URL: http://zakon.rada.gov.ua (дата звернення 26.06.2021).

9. Загальний Класифікатор «Галузі народного господарства України». URL: http://zakon.rada.gov.ua (дата звернення 26.06.2021).

10. Транспорт і зв'язок України у 2018. Статистичний збірник. К.: Державна служба статистики України. 2019. 153 с.

11. Класифікація видів економічної діяльності КВЕД-2010 клас 50.40 Вантажний річкових транспорт. URL: https// search.ukr.net/?g=квед 50.40\#gsc.tab=08 (дата звернення 25.06.2021).

12. Гончарук О. Зелена книга «Вантажні перевезення внутрішніми водними шляхами». URL: https://cdn.regulation/gov.uа (дата звернення 26.06.2021).

13. Розміри плати в редакції Постанов КМ № 994 від 20.06.2000, № 880 від 01.07.2002, № 350 від 15.04.2009, №553 від 16.10.2014; із змінами внесеними згідно з Постановою КМ № 140 від 24.02.2021. URL: http://zakon.rada.gov.ua/laws/show/236-99-n\#Text (дата звернення 26.06.2021).

14. Закон України «Про внутрішній водний транспорт» №1054-IX. URL: seach.ligazakon.ua/1_doc2.nsf/link1/T201054.html (дата звернення 26.06.2021).

15. Седіков Д. В., Седікова І. О. Управління витратами у логістичних ланцюгах зернопереробних підприємств. Східна Європа: економіка, бізнес та управління. 2019. Вип. 1 (18). C. 197-201.

\section{References:}

1. Krykavskyi Ye. V. (2014). Navchalno-metodychnyi posibnyk [Training manual]. Lviv: Vydavnytstvo Lvivskoi politekhniky. 196 p. (in Ukrainian).

2. Novopisna Ye. V. (2009). Faktory formuvannia lohistychnykh vytrat pidpryiemstva. Upravlinnia proiektamy ta rozvytok vyrobnytstva [Factors in the formation of logistics costs of the 
enterprise. Project management and production development] : Zb. nauk. pr. Luhansk: vyd-vo SNU im. V. Dalia. [Coll. Science. Lugansk Ave.: published by SNU. V. Dahl]. Vol. 4 (32). p. 123-129. (in Ukrainian).

3. Oklander M. A. (2008). Lohistyka: Pidruchnyk [Logistics: Textbook] K.: Tsentr uchbovoi literatury. 346 p. (in Ukrainian).

4. Reta M. V. (2012) Lohistychni vytraty: vyznachennia, klasyfikatsiia ta oblik [Logistics costs: definition, classification and accounting]. Biznesinform. Vol. 8. p. 155-158. (in Ukrainian).

5. Savenko I. I. Sedikov D. V. (2020) Lohistychnyi menedzhment, yak instrument optymizatsii lohistychnykh vytrat [Logistics management as a tool for optimizing logistics costs] Ekonomika kharchovoi promyslovosti [Economics of the food industry.]. Odessa. Vol. 3 Iss. 12.p. 42- 50. (in Ukrainian).

6. Sumets O. M. (2017) Lohistychni vytraty pidpryiemstv oliino-zhyrovoi haluzi: formuvannia ta otsiniuvannia: monohrafiia [Logistic costs of enterprises of the oil and fat industry: formation and evaluation: a monograph]. Kharkiv : Vyd-vo NUA. 243 p. (in Ukrainian).

7. Lehenkyi H. (2000). Problemy rozvytku tranzytnykh perevezen ta shliakhy yikh vyrishennia [Problems of development of transit transportations and ways of their decision]. Ukraine economy. Vol. 7. p. 8. (in Ukrainian).

8. Zakon Ukrainy «Pro transport» № 232/94-VR vid 10.11.1994. [Law of Ukraine «On Transport» № 232/94-BP of November 10, 1994.] Retrieved from: http://zakon.rada.gov.ua/laws/ show/232/94-vr\#Text

9. Zahalnyi Klasyfikator «Haluzi narodnoho hospodarstva Ukrainy» [General Classifier «Branches of the national economy of Ukraine»]. Retrieved from: http://zakon.rada.gov.ua.

10. Transport i zviazok Ukrainy u 2018. Statystychnyi zbirnyk (2019) [Transport and Communications of Ukraine in 2018. Statistical collection]. K.: Derzhavna sluzhba statystyky Ukrainy [State Statistics Service of Ukraine]. 153 p.

11. Klasyfikatsiia vydiv ekonomichnoi diialnosti KVED-2010 klas 50.40 Vantazhnyi richkovykh transport [Classification of economic activities NACE-2010 class 50.40 Freight river transport]. Retrieved from: https// search.ukr.net/?g=kved 50.40\#gsc.tab=08.

12. Honcharuk O. (2017). Zelena knyha «Vantazhni perevezennia vnutrishnimy vodnymy shliakhamy» [Green Paper on Inland Waterways Freight]. Retrieved from: https://cdn.regulation/gov.ua/2e/35/eb/bc/regulation/gov.ua. (in Ukrainian).

13. Rozmiry platy v redaktsii Postanov KM № 994 vid 20.06.2000, № 880 vid 01.07.2002, № 350 vid 15.04.2009, № 553 vid 16.10.2014; iz zminamy vnesenymy zghidno z Postanovoiu KM № 140 vid 24.02.2021 [Amounts of the fee in the wording of the Resolutions of the Cabinet of Ministers № 994 dated 20.06.2000, № 880 dated 01.07.2002, № 350 dated 15.04.2009, №553 dated 16.10.2014; with changes made in accordance with the Resolution of the Cabinet of Ministers № 140 of 24.02.2021]. Retrieved from: http://zakon.rada.gov.ua/laws/show/236-99-n\#Text.

14. Zakon Ukrainy «Pro vnutrishnii vodnyi transport» №1054-IKh [Law of Ukraine «On Inland Water Transport» 541054-IX]. Retrieved from: seach.ligazakon.ua/1_doc2.nsf/link1/T201054.html.

15. Sedikov D.V., Sedikova I.O. (2019). Upravlinnia vytratamy u lohistychnykh lantsiuhakh zernopererobnykh pidpryiemstv [Cost management in logistics chains of grain processing enterprises]. Eastern Europe: Economy, Business and Management. Vol. 1 (18). p. 197-201. (in Ukrainian). 